\title{
SOBRE BURTON E \\ A CONSTRUÇÃO DOS DISCURSOS EUROPEUS \\ SOBRE OS AFRICANOS
}

GEBARA, Alexsander. A África de Richard Francis Burton: antropologia, política e livre-comércio, 1861-1865. São Paulo: Alameda, 2010. 256p.

A lexsander Gebara nos mostra com grande destreza como inovar o estudo de um tema que poderia parecer já esgotado: os itinerários intelectuais e a vida aventurosa de Sir Richard Francis Burton (18211890), personagem quase lendário e notável participante da produção dos discursos europeus sobre o Oriente e a África que tiveram curso em sua época. Poliglota, Burton traduziu do árabe para o inglês $A s$ mil e uma noites, deleitando-se em realçar os aspectos eróticos dos seus contos para escandalizar os pudores da Inglaterra vitoriana (colaborou também na publicação em inglês do Kama Sutra). Traduziu Os Lusíadas e outros poemas de Camões e planejou escrever uma gramática tupi-guarani (sua esposa, Lady Isabel Arundell Burton, traduziu Iracema, de José de Alencar). O casal Burton viveu em nosso país de 1865 a 1868 , enquanto ele foi cônsul britânico em Santos. Dividiram o seu tempo entre Santos e São Paulo, com idas também ao Rio de Janeiro e a Petrópolis, e ao interior do Brasil. Richard Burton visitou a cachoeira de Paulo Afonso e conta isso em seu livro The
Highlands of Brazil. Além disso, foi ver com os próprios olhos alguns dos campos de batalha da Guerra do Paraguai, que se desenrolava na época em toda a sua ferocidade. $\mathrm{O}$ imperador Dom Pedro II, que já o conhecia de fama, convidou-o a jantar, fez questão de ir assistir a palestras suas e deu-lhe outras demonstrações de estima.

A fama de Burton se derivava em boa parte da viagem (em 1853) que fizera disfarçado a Meca e Medina, cidades proibidas aos não muçulmanos, e do relato dessa viagem que publicara em 1855-1856, Personal Narrative of a Pilgrimage to El-Medinah and Meccah. Falava perfeitamente o árabe e era bem enfronhado nos pormenores da cultura islâmica, que observara e estudara no subcontinente indiano no período que ali passara como militar, de 1842 a 1849 , após ser expulso do Trinity College da Universidade de Oxford. Pudera, assim, fazer a sua "peregrinação" à Arábia viajando sob identidades falsas como a de "Xeque Abdullah", supostamente um muçulmano perito em medicina, e completara a sua arriscada visita sem ser desmascarado. 
Outra das suas viagens, a expedição que fez em 1857-1859 à região dos Grandes Lagos na África Oriental, em companhia de John Hanning Speke, reforçara a sua notoriedade, mas também a complicara. A desinteligência entre os dois exploradores a respeito das nascentes do rio Nilo se tornou querela pessoal e terminou tragicamente com a morte de Speke na Inglaterra, em 1864, possivelmente por suicídio, na véspera de um debate público com Burton na cidade de Bath. A narrativa da expedição continua atraindo até hoje a atenção e a imaginação de muitos. Há dois anos, encontrei em Montpellier uma versão dela em formato de história em quadrinhos: Captain Sir Richard Burton - Vers les sources $d u$ Nil, publicada por Christian Clot (membro da Société des Explorateurs Français) e Alex Nikolavitch (Grenoble: Glénat, 2012).

Biografias de Burton existem, e textos dele têm sido escrutinados por críticos como Edward W. Said (em seu livro Orientalism) e outros. Mas o estudo que Gebara nos oferece tem a originalidade de estar focalizado em textos que Burton produziu durante um período da sua vida relativamente pouco estudado, que se seguiu à sua viagem aos Estados Unidos em 1860, durante a qual atravessara o faroeste viajando de diligência e visitara e descrevera os mórmons de Salt Lake City, assim como aldeias ameríndias dos Sioux e dos Dakota.

Durante os anos 1861-1864, imediatamente anteriores à sua vinda ao
Brasil, Burton foi o cônsul britânico na ilha de Fernando Pó, ao largo da costa atlântica da África. $\mathrm{Na}$ época possessão colonial espanhola, a ilha - com o nome mudado para Bioco - é hoje parte da República da Guiné Equatorial, cuja capital, Malabo, nela se situa. De Fernando Pó, Burton fez viagens ao lado oeste do continente africano, das quais escreveu relatos.

Gebara desenvolve uma sofisticada análise textual interna dos relatos de Burton sobre a região do delta do rio Níger e a cidade iorubá de Abeokuta (ambas hoje incluídas na República Federal da Nigéria) e sobre o reino do Daomé (hoje parte da República do Benim). Salienta com perspicácia as múltiplas nuances, idiossincrasias e tensões internas dessas narrativas. A leitura que delas faz é uma aula teórica e prática de como evitar simplismos, anacronismos e indignações fáceis (mas rasas) na interpretação da literatura desse tipo, mesmo quando pode hoje nos chocar e provocar aversão - como é frequentemente o caso com os escritos de Burton sobre a África e outras partes não europeias do mundo. Para darmos um só exemplo não africano, Burton descreveu os paraguaios como gente pré-histórica, "paleozoica", embora reconhecesse neles um heroísmo "raro nos anais da humanidade" e uma "Esparta pele-vermelha" comparável à Esparta da Grécia antiga.

Ao mesmo tempo, Gebara faz uma contextualização igualmente so- 
fisticada dos relatos de Burton, situando-os nos debates científicos e político-ideológicos de que foram parte ativa dentro da elite britânica, trazendo à tona as contraditórias correntes de pensamento e os divergentes projetos políticos que se entrecruzavam naqueles debates. Outras publicações de Burton e sua correspondência oficial e pessoal são também cuidadosamente utilizadas na análise. Vale acrescentar que o período 1861-1864 é especialmente importante do ponto de vista da evolução das representações do "outro" (os não europeus), tanto no pensamento de Burton quanto no ambiente cultural britânico em geral.

Gebara aborda o estudo desses processos a partir da investigação de quatro dimensões inseparáveis: "o contexto histórico das regiões visitadas e descritas [por Burton]; o discurso 'científico' geográfico e antropológico 'europeu'; a política ou ação política inglesa para a região da África Ocidental no período; a estrutura social inglesa e a posição de Burton, tanto nessa estrutura quanto na burocracia do Estado inglês" (p.18). O terceiro capítulo do livro ("O lugar de Burton na Inglaterra") desenvolve uma discussão particularmente interessante a respeito da Royal Geographic Society, da Anthropological Society of London e da London Ethnological Society. Inclui também um exame crítico do argumento de que foi como reação conservadora a transformações sociais que ocorriam na própria Ingla- terra que foram elaboradas no país, na segunda metade do século XiX, "representações de exclusão dos trabalhadores e das classes baixas, que posteriormente se estenderam aos negros, identificados ao trabalho manual e à escravidão" (p.143). Gebara reconhece que esse argumento constituiu uma etapa importante da indagação histórica, mas mostra que a construção daquela nova imagem do negro foi gerada por uma dinâmica ainda mais complexa, por um lado, "resultado da expansão imperial e de sua necessidade de legitimação" e, por outro lado, "credora das transformações sociais na "metrópole" " (p.134, 237).

Em suas "Considerações finais", Gebara ressalta um paradoxo. O discurso imperialista do final do século XIX surge de uma dinâmica relacional entre africanos e europeus, tanto na esfera político-econômica quanto na própria esfera discursiva. Foi um discurso mais interativo do que parece à primeira vista, pois, em certa medida, refletiu e respondeu às iniciativas de resistência ou adaptação em que se empenharam muitos africanos, e determinados aspectos dele podiam ser confiscados e habilmente utilizados, por certos protagonistas africanos em prol dos seus próprios interesses. Assim sendo, de maneira imprevista, o discurso eurocêntrico revela a participação da África e dos africanos no "campo da agência histórica", ao mesmo tempo em que exprime "uma visão negativista da 'raça negra"” (p.243). 
Fiquem os leitores prevenidos de que, infelizmente, o livro foi impresso sem revisão atenta das suas provas tipográficas. Há gritantes erros de impressão em algumas das suas páginas. Mas é preciso não per- mitir que isso nos distraia da importância da pesquisa e das reflexões de Gebara, que são um tento marcado com perícia pela historiografia brasileira contemporânea.

Paulo Fernando de Moraes Farias p.f.de_moraes_farias@bham.ac.uk Universidade de Birmingham, Inglaterra 